\title{
Petrus Socraticus? Socratic Reminiscences in Luke's Portrait of the Apostle Peter
}

\author{
Matthias Becker \\ Universität Göttingen, Theologische Fakultät (Seminar für Neues Testament), \\ Platz der Göttinger Sieben 2, D-37073 Göttingen; matthias.becker@theologie.uni-goettingen.de
}

For citation: Matthias Becker. Petrus Socraticus? Socratic Reminiscences in Luke's Portrait of the Apostle Peter. Philologia Classica 2020, 15 (1), 54-71. https://doi.org/10.21638/spbu20.2020.105

New Testament scholars have long argued that in Acts 17:16-34 Luke depicts Paul in such a way as to evoke Socrates' modus philosophandi and to echo his trial and apology. While this argument can be based on sufficiently clear philological indications, there are other, comparatively vague and more general Socratic reminiscences in Luke-Acts, e. g. in the Gethsemane episode which shows that for the Lukan Jesus death is not a terrifying prospect. This study reads Luke's portrayal of the apostle Peter through the lens of the exemplum Socratis as presented by Greek and Roman intellectuals in the first and early second centuries CE, including Dio Chrysostom, Epictetus, Plutarch, and Seneca. The author argues that the humble origins of Peter, his non-academic profession, his poverty, his lack of formal education, and his unbreakable commitment to obey God and to spread the Christian message in spite of the threat of judges are reminiscent of major elements of the reception of Socrates in the period that Luke-Acts was probably composed (c. 80-100 CE). Highlighting the subtle Socratic components in Luke's depiction of Peter not only helps to shed new light on Peter's alleged lack of education (Acts 4:13). It also helps to understand, firstly, how the literary depiction of early Christian teaching figures is shaped by roughly contemporaneous philosophical discourses, and secondly, that Peter's literary image, although it presents a totally different type of teaching figure than Paul, serves in its own way to exemplify the compatibility of the Christian religion with particular strands of ancient philosophy.

Keywords: New Testament, Luke-Acts, Peter, Socrates, Greco-Roman education, (il-)literacy.

New Testament scholars have repeatedly argued, and rightly so, that in Acts 17:1634 the early Christian author Luke presents Paul in overtly Socratic terms. ${ }^{1}$ In this famous passage, unparalleled in the New Testament, the missionary's sojourn in Athens, which in the undisputed Pauline letters is mentioned merely in passing, ${ }^{2}$ is creatively transformed into a literary encounter between Christianity and ancient philosophy. ${ }^{3}$ Striking allusions to the exemplum Socratis include, firstly, Paul's "daily conversations" in the city's "mar-

* This study is partly based on my Habilitationsschrift, which was submitted to and accepted by the Faculty of Theology of the University of Göttingen in 2019 (Becker 2020). Unless otherwise indicated, all translations of ancient texts are my own. I am very grateful to T. R. Niles (Göttingen) for helpful comments and for editing my English. I would also like to express my gratitude to the anonymous reviewers of Philologia Classica for their useful feedback.

1 For recent discussion, see Keener 2014, 2580, 2598; Hilton 2018, 144-145.

21 Thess 3:1.

3 Cf. Acts 17:18; Rowe 2011; Vollenweider 2012; Prostmeier 2013, 127-141.

(C) St. Petersburg State University, 2020 


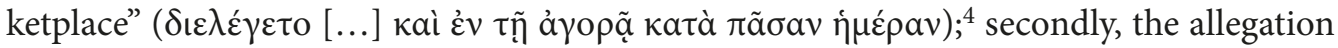

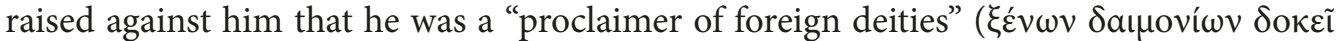

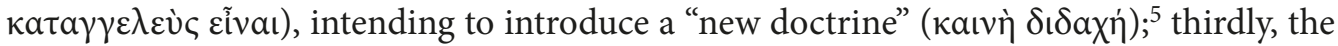
fact that he was brought to the Areopagus to be tried on that charge; ${ }^{6}$ and fourthly, the speech Paul delivers which contains a number of references to philosophical topics and traditions commonly associated with the figure of Socrates. ${ }^{7}$ Paul, however, is not the only protagonist in Luke-Acts dressed up, at least episodically, in Socratic garb. ${ }^{8}$ Rather, he is joined by Jesus and, as I shall argue, by Peter. Scholars have been comparing Jesus with the Greek philosopher for more than two centuries. ${ }^{9}$ Socratic reminiscences mainly concern his death, which the auctor ad Theophilum pointedly presents, in contrast to Mark's and Matthew's accounts, as a mors philosophi: Jesus' prayerful trust in the will of God that prevents him from suffering an emotional breakdown in the garden of Gethsemane, ${ }^{10}$ his trial as well as his way of viewing death and his way of dying reveal a kind of tranquil steadfastness that finds its classical counterpart in the noble death of Socrates. ${ }^{11}$

As regards Peter, with the exception of commentators looking for parallels to specific verses, ${ }^{12}$ not many classicists or New Testament scholars have hitherto endeavoured to view Luke's literary portrayal through a specifically Socratic lens. ${ }^{13}$ However, Peter seems also suited for a comparison with the Athenian philosopher, especially if one takes the reception of Socrates in the early imperial period into account. After all, Plato's image of a highly intelligent and cultivated Socrates who engages in philosophical, literary and scientific discourse does not, despite its massive influence on ancient philosophy and literature, represent the whole, multi-faceted picture that later intellectuals have constructed of him. ${ }^{14}$ Taking up a suggestion made by the German New Testament scholar Udo Schnelle, who points out that the education of New Testament authors and their respective

4 Acts 17:17; cf., e. g., Plat. Apol. 17c; Xen. Mem. 1.2.33; Epict. Diss. 4.4.21; Diog. Laert. Vit. phil. 2.21.

5 Acts 17:18-19; cf., e. g., Plat. Apol. 24b-c, 26b; Xen. Mem. 1.1.1-3; Xen. Apol. 10; Max. Tyr. Diss. 3.8; Diog. Laert. Vit. phil. 2.40.

6 Acts 17:19-20.

7 Döring 1979, 152; Jantsch 2017. The philosophical topics Torsten Jantsch identifies as Socratic include theological cosmology, divine providence, the invisibility of the gods, the similarity between the human and divine natures, divine self-sufficiency, and the inappropriateness of paying (cultic) homage to deities. In an article soon to be published, J. Andrew Cowan argues that Luke in Paul's oratio Areopagitica implicitly interacts with Plato's Euthyphro and the Apology, showing interest, specifically, in aspects of Socratic thought as represented in traditions about his trial (Cowan, forthcoming).

${ }^{8}$ For further Socratic elements in Luke's portrayal of Paul, see Heininger 2007, 413-414.

9 See, e. g., Priestly 1803; Wenley 1889; Bostick 1916; Gooch 1996; van Kooten 2017. For the ancient roots of the comparison of Christ and Socrates, see Justin. Mart. 2 Apol. 10.8; Hanges 2006, 143-150.

${ }^{10}$ Luke 22:39-46. The Markan (Mark 14:32-42) and Matthean (Matt 26:36-46) versions differ considerably as regards Jesus' coping with his immanent death.

${ }^{11}$ For a thorough study on the philosophical tendencies in Luke's versions of the Gethsemane episode and the crucifixion scene (Luke 23:33-48), which are different from those of Mark and Matthew, see Sterling 2001. Jesus' ultima verba are a case in point: The desperate and emotional cry of the Markan and Matthean Jesus "My God, my God, why have you forsaken me" (Mark 15:34; Matt 27:46), is replaced with the more confident words "Father, into your hands I commit my spirit" (Luke 23:46).

12 See, e. g., Keener 2013, 1157 (Acts 4:13), 1161 (Acts 4:18-22), 1218 (Acts 5:29).

13 Hilton 2018, 145-148, with his conclusions on the philosophical traits of Peter in Acts 4 and 5, does break new ground. But he does not offer a typology of Socratic reminiscences in Luke's general portrayal of Peter.

14 Differing and nuanced portraits of Socrates emerge early, as even a superficial look at the Platonic and Xenophontic Socrates reveals (Danzig 2010). For an analysis of the reception of Socrates in the Hellenistic, imperial, and late antique periods, see Döring 1979; Moore 2019. 
audiences should be evaluated primarily within the context of contemporaneous GrecoRoman literature, philosophy, and culture, ${ }^{15} \mathrm{I}$ take as the main basis of my study not the writings of Plato or Xenophon, but a selection of those of Valerius Maximus (first half of the first century CE), Seneca (c. 4-65 CE), Musonius Rufus (c. 30-100 CE), Dio Chrysostom (c. 40-c. 115 CE), Plutarch (c. 45-c. 120 CE), and Epictetus (c. 55-c. 135 CE). All of these rhetoricians, philosophers and writers have transmitted historical traditions about Socrates, but through selection and interpretation they have also shaped the cultural image of Socrates on their own terms. Taking Udo Schnelle's approach seriously means that the auctor ad Theophilum and his predominantly Gentile Christian audience, who represent a branch of first-century Christianity in which biblical theology merges with Greco-Roman education, ${ }^{16}$ did not necessarily have to have carefully read Plato or Xenophon themselves in order to be acquainted with Socratic traditions. ${ }^{17}$ Rather, it is important to underscore that they were most probably familiar with all kinds of contemporaneous discourses about rhetorical, ethical, theological, and (popular) philosophical issues (including quotes from Plato's dialogues on the exemplum Socratis), in which the writings of the above-mentioned $\pi \varepsilon \pi \alpha \iota \delta \varepsilon v \mu \varepsilon \dot{v}$ ol participate. ${ }^{18}$

Looking at first and early second-century receptions of Socrates, which are roughly contemporaneous with the probable date of composition of Luke-Acts between circa 80$100 \mathrm{CE},{ }^{19} \mathrm{I}$ argue that there are interesting analogies to be considered concerning, firstly, Peter's humble origins and non-academic occupation, secondly, his poverty, thirdly, his lack of a formal education, and fourthly, his commitment to obey God under the pressure of hostile judicial hearings. While the first and second analogies are somewhat vague, the third and fourth analogies form the core of my argument. The findings of this study make it seem likely that the auctor ad Theophilum uses different components of the multifaceted picture of Socrates of his day to highlight different aspects in the portrayals of his protagonists. Certain nuances of the multifarious image of Socrates in Luke's lifetime are reflected, as it were, in different literary characters in Luke-Acts. While the Lukan Paul and the Lukan Jesus are primarily modelled, at least in part, after the Socrates moriens (Jesus) and the Socrates philosophans (Paul), the Lukan Peter is, at least in part, reminiscent of a Socrates who pleads (intellectual) simplicity as well as obedience to the god and who rejects erudition as a prerequisite for wisdom.

15 Schnelle 2015, esp. 120-121, 140-141; cf. further Becker 2020, 35-51, at 40.

16 Feldmeier 2012, 77-80, 92-93; Becker 2020, 30, 632-635; cf. also Vollenweider 2012, 305. Feldmeier 2012, 77 rightly describes Luke-Acts as "a precursor of the conjunction of biblical faith and Hellenistic education"; see also ibid. 92: Luke's "work represents a milestone on the difficult path of early Christianity towards the appropriation of Greek education and culture without renouncing its own identity."

17 Without precluding the possibility that Luke (and his audience) had first-hand knowledge of

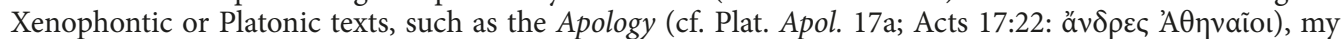
main point here is that the reception of Socrates was so vivid in the first and early second centuries CE that Luke (and his audience) could (also) draw from contemporaneous second-hand knowledge preserved and diffused by educated discourse.

18 See Becker 2020, 35-61 for more evidence supporting this assumption and for a more thorough account of my general approach.

${ }_{19}$ Cf. Schnelle 2016, 332 (around 90-100 CE); Adams 2019, 146 (around 80-90 CE). Schnelle and Adams follow the majority of scholars, and so do I. 


\section{Humble Origins and Occupation}

As is well known, Peter, unlike Paul, does not come from a city renowned for its educational institutions: While Paul in his letters never mentions the place where he was born and brought up ${ }^{20}$ Luke is the only New Testament author who mentions Paul's home town Tarsus. In fact, he states the name three times, thereby highlighting, though in somewhat encrypted fashion, the educational background of one of his most important protagonists. ${ }^{21}$ By contrast, and in accordance with the synoptic tradition, Peter is depicted as hailing from Capernaum, ${ }^{22}$ a place that the Jewish historian Josephus calls a "village"

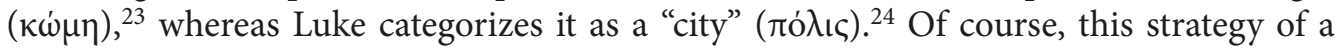
literary urbanization is distinctive of Luke-Acts as a whole, ${ }^{25}$ and it also enhances the significance of Jesus' public activity in Capernaum by creating the impression that his ministry takes place in an urban setting. ${ }^{26}$ At the same time, the term $\pi$ ó $\lambda$ ı hide the rural origins of Peter's family. Despite his attempt to locate Peter's home within an urban environment, the information Luke includes in his gospel generally indicates that he does not belong to the upper stratum of society. After all, he is introduced as a Galilean fisherman, and only after he meets Jesus does he turn his back on fishing. ${ }^{27}$ It is this portrayal of a simple man with a non-elitist background that is reminiscent of Socrates. Notwithstanding that he comes from the famous intellectual city of Athens, ${ }^{28}$ writers in the early imperial period are well aware of the "ill repute" (á $\delta \circ \xi \dot{\xi} \alpha)$ commonly associated with the fact that he was not of noble birth. ${ }^{29}$ As Seneca quite bluntly puts it: "Socrates was not of patrician rank" (patricius Socrates non fuit)..$^{30}$ According to tradition, his mother Phaenarete worked as a midwife, and his father Sophroniscus was a sculptor. ${ }^{31}$ Before devoting himself to philosophy, Socrates was said to have practiced the craft of masonry,

${ }^{20}$ As Vegge 2006, 425-442 rightly points out, this fact does not imply that Luke's information about Paul's birthplace is historically questionable.

21 Acts 9:11; 21:39; 22:3; cf. Heininger 1998, 130-133. In Luke's day, Tarsus was famous for its schools of rhetoric and philosophy and it had an excellent reputation in the advancement of "general education"

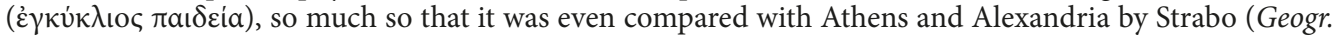
14.5.12-15).

22 Luke 4:38; parr. Mark 1:29; Matt 8:14. Another aspect that applies both to Peter and to Socrates and which does not figure at all in Luke's portrayals of Jesus or Paul is marriage (Luke 4:38; cf. Mark 1:30; Matt 8:14; 1 Cor 9:5). Socrates' marital relationship with Xanthippe was well known during Luke's lifetime; see, e. g., Sen. Epist. 104.27; Valer. Max. Fact. et dict. mem. 7.2 ext. 1; Muson. Diatr. 14, p. 70.11-71.1 Hense; Epict. Diss. 3.26.23; 4.1.159; Plut. De cap. ex inimic. util. 90e.

${ }^{23}$ Joseph. Vita 403. In Strabo's account of the region surrounding the Sea of Galilee, the fishing village Capernaum is not even mentioned, although he does touch upon the adjacent town of Tarichaea, which was famous for its pickled fish (Strab. Geogr. 16.2.45; cf. also Joseph. Vita 404).

${ }^{24}$ Luke 4:31; diff. Mark 1:21.

${ }^{25}$ Cadbury $^{2} 1958,245-249$.

26 Luke 4:31-41; Wolter 2008, 201.

27 Luke 5:1-11; cf. Mark 1:16-20; Matt 4:18-22.

28 Dio Chrys. Orat. 55.8; cf. Diog. Laert. Vit. phil. 2.18.

29 Plut. Frg. $140^{\star}$ Sandbach; cf. Valer. Max. Fact. et dict. mem. 3.4 (init.); 3.4 ext. 1 (Socrates included among the humili loco nati). In the same paragraph, Valerius Maximus makes clear that people, despite being of humble birth, can indeed become famous, and he refers to Socrates, Euripides, Demosthenes, and others as examples (Valer. Max. Fact. et dict. mem. 3.4 ext. 1-2).

30 Sen. Epist. 44.3. In the same paragraph, Seneca also mentions the Stoic Cleanthes who used to work as a water carrier for a gardener to earn a living; cf. Diog. Laert. Vit. phil. 7.168-169.

31 Valer. Max. Fact. et dict. mem. 3.4 ext. 1; Plut. Frg. 140 Sandbach; cf. also Diog. Laert. Vit. phil. 2.18; Becker 2016a, 23. 
too, following in his father's footsteps. ${ }^{32}$ Thus, besides being born into non-intellectual families, Peter and Socrates have in common that they started out as crafts- or tradesmen, who nevertheless decide to adopt a life of austerity, even poverty.

\section{Poverty}

Within the context of first century Christianity, Luke clearly can be considered one of the fiercest opponents of luxury, avarice, and wealth, paying more attention to these issues than any other evangelist. ${ }^{33}$ Although he also depicts well-to-do Christians, ${ }^{34}$ the central teaching figures of Luke-Acts, such as Jesus, ${ }^{35}$ Paul, ${ }^{36}$ and Peter generally live a simple life, partly displaying poverty ostentatiously, partly criticizing wealth severely. Hence, potential Socratic reminiscences concerning poverty are definitely not limited to the depiction of Peter, but they constitute, so to speak, one piece in the overall Socratic mosaic of the apostle. In Luke's day, although impoverishment and voluntary abnegation of wealth were generally associated with the philosophical modus vivendi, ${ }^{37}$ the Athenian philosopher himself was particularly well-known for his poverty. ${ }^{38}$ Interestingly, to abandon earthly property for the sake of following Jesus is an important point that Peter makes in Luke 18:28 (parr. Mark 10:28; Matt 19:27), saying: "See, we have followed you, leaving behind

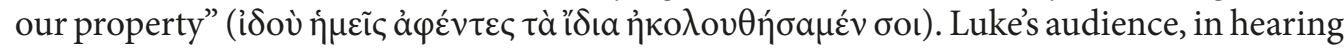
this phrase, can think back to chapter 5:11, where the text says that after Peter, James and John had witnessed the miraculous catch of fish made possible by Jesus, ${ }^{39}$ they "followed

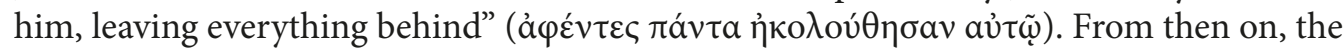
narrative presents Peter as living a simple itinerant life like the other disciples, and when Jesus sends them out, he plainly states that this is exactly what he expects of them while proclaiming the kingdom of God and healing people: "Do not take anything with you on

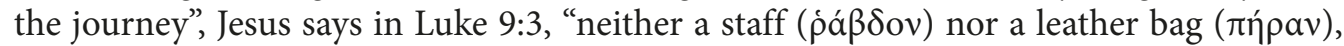

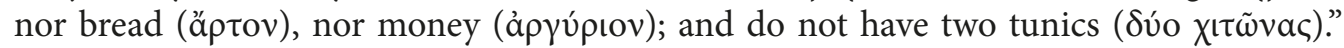
While this demand seems to have a specifically Cynic ring to it, ${ }^{40}$ it should be noted that, although Diogenes is to be considered the "Prototyp des wahren Kynikers", Cynicism in

32 Dio Chrys. Orat. 55.2; cf. Diog. Laert. Vit. phil. 2.19.

33 See, e. g., Hays 2010; Kramer 2015.

34 Cf. Acts 16:14-15.

35 Luke 6:20-21; 6:24-25; 9:58; 12:13-34.

36 Acts 20:33.

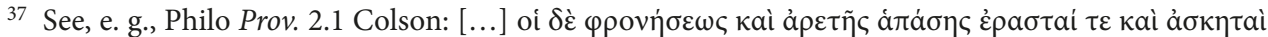

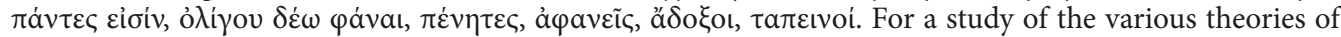
poverty in New Testament times, see Armitage 2016.

38 See, e. g., Philo Prov. 2.21 Colson; Sen. Epist. 104.27; Dio Chrys. Orat. 3.1; 54.2; Plut. Arist. 1.9; Quomodo quis suos in virt. 84f; De genio Socr. 582b; cf. also Max. Tyr. Diss. 1.9; 18.5; 39.5; Diog. Laert. Vit. phil. 2.31. The image of the Socrates pauper ultimately goes back to Plato's famous lines in Apol. 23b-c: [...]

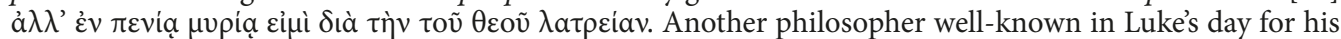
poverty was Diogenes, see, e. g., Dio Chrys. Orat. 6 and 10.

39 Luke 5:1-11; cf. Mark 1:16-20; Matt 4:18-22.

40 Typical features of Cynic apparel include a filthy "cloak" ( $\tau \rho i \beta \omega v$ or $\tau \rho \iota \beta \dot{v} \nu\llcorner o v)$, a "leather pouch"

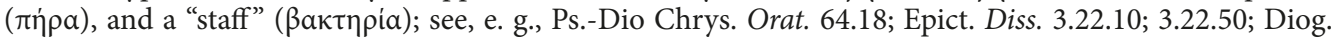
Laert. Vit. phil. 6.13; cf. further Billerbeck 1978, 56-57; Horn ${ }^{2} 1986,195-199$. Since the Hellenistic period, the habit of wearing a simple cloak became a general characteristic of philosophers who embraced asceticism, being ultimately inspired by the example of Socrates (Plat. Symp. 219b; Billerbeck 1978, 56). 
the Hellenistic and imperial periods heavily relied on the role model of Socrates. ${ }^{41}$ In addition, there is another instance in Luke-Acts where Peter confesses his poverty in a more general sense. Initiating the healing of the lame beggar at the Beautiful Gate of the temple in Jerusalem, ${ }^{42}$ Peter says in Acts 3:6: "Silver and gold I do not possess, but what I do have I give to you: In the name of Jesus Christ the Nazorean, [rise and] walk around!"

\section{Lack of Education}

While Peter's humble origins, his non-academic occupation and voluntary poverty are somewhat vague with regard to the literary socratization of the apostle, his lack of education and his commitment to obey God constitute more persuasive evidence. In Acts 4:13, the reader encounters an unusual phenomenon: Using Jesus' disciples Peter and $\mathrm{John}^{43}$ as examples, Luke puts the narrative spotlight on the lack of education that characterizes some of his teaching figures. When Luke speaks elsewhere about the educational background of his protagonists, he usually makes affirmative statements about the value of learning, focusing partly on aspects of Jewish education, partly on Greek literary and rhetorical $\pi \alpha i \delta \varepsilon i a .{ }^{44}$ Hence, Moses is depicted as erudite in the sense that he was taught the barbarian "wisdom" of the Egyptians; ${ }^{45}$ Paul is said to have studied in Jerusalem under Gamaliel the Elder; ${ }^{46}$ the Hellenistic Jewish teacher and missionary Apollos, a native of

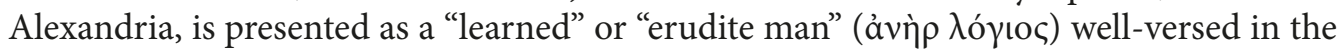
sacred writings of the Jews and thereby possessed of distinctive features which indicate an intellectual and philological profile reminiscent of Philo of Alexandria; ${ }^{47}$ and even Jesus is never portrayed as a "carpenter" nor as the "son of a carpenter" in Luke-Acts, which marks a striking difference when compared with the Markan and the Matthean narratives. ${ }^{48}$ Against this backdrop, the portrayal of Peter and John in Acts 4:13 seems odd at first glance. Before putting this verse into its larger discourse context, its immediate literary context has to be briefly considered. After healing a lame beggar at the Beautiful Gate of the temple in Jerusalem, ${ }^{49}$ Peter delivers a long sermon in Solomon's Portico ${ }^{50}$ and sub-

41 Billerbeck 1978, 6-9, at 7 (quote).

42 Acts 3:1-10.

${ }^{43}$ Cf. Luke 6:13-14; parr. Mark 3:14-17; Matt 10:1-1-2. The following content of section 3 is largely based on Becker 2020, 615-621, with modifications.

44 Plümacher 1972, 19-23; Feldmeier 2012, 82-83.

45 Acts 7:22. For a similar, but more creative attempt to fill in the narrative gaps in the Exodus account

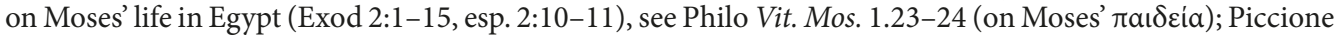
2004.

46 Acts 22:3; Burchard 1970, 35-36. Furthermore, Luke is eager to picture Paul as a brilliant speaker throughout Acts (Plümacher 1972, 22; Keener 2012, 264).

${ }_{47}$ Acts 18:24-19:1, esp. 18:24; Wehnert 2013. For a thorough analysis of Philo's thought, see Niehoff 2018; for the scholarly context of his work in Alexandria, see Niehoff 2011.

${ }^{48}$ In Mark 6:3, Jesus is presented as "the carpenter" ( $\dot{o} \tau \dot{\varepsilon} \kappa \tau \omega v$ ), while in Matt 13:55 he is introduced

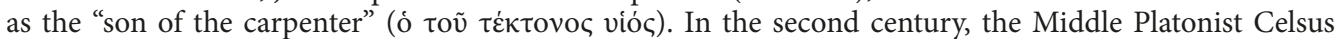
obviously had knowledge about Jesus' manual occupation as evidenced in Mark 6:3, which led him to make fun of early Christian formulae: Popular phrases among the Christians, such as "wood/tree of life" ( $\tau \tilde{\eta} \varsigma$

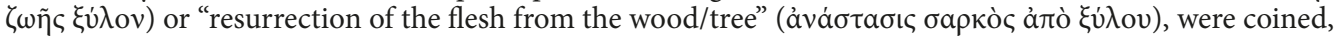
according to Celsus, because "their teacher was nailed to a cross and was a carpenter by trade ( $\tau \dot{\kappa} \kappa \tau \omega \nu \tau \eta \dot{\nu}$ $\tau \varepsilon \dot{\chi} \chi \eta v)$ )" (apud Orig. Cels. 6.34); cf. Andresen 1955, 176.

49 Acts $3: 1-10$.

50 Acts 3:11-26. 
sequently is arrested together with John and others to be questioned by the Sanhedrin. ${ }^{51}$ Luke's main point in describing the reaction of the members of the council to Peter's and John's answers is to highlight their surprise. As Luke puts it, the Sanhedrin, being unaware of Peter's empowerment by the holy Spirit as presented in Acts 4:8, obviously did not expect seemingly uneducated people to be so outspoken:

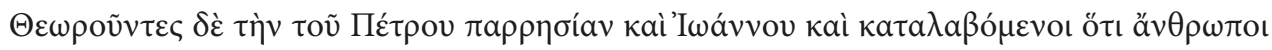

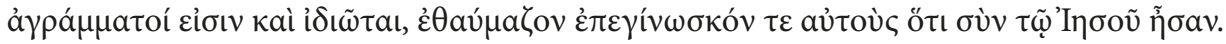

But when they observed the boldness ( $\pi \alpha \rho \rho \eta \sigma i a)$ of Peter and John and noticed that they

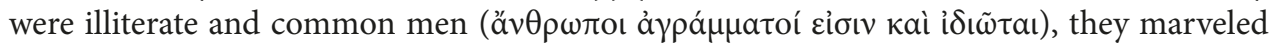
and recognized that they had been with Jesus. (Acts 4:13)

Since Peter and John are introduced in his passage specifically as disciples of Jesus

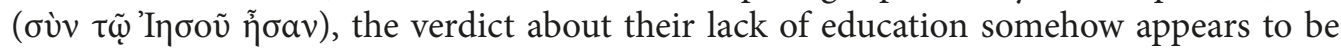
aimed at the Jesus movement as a whole. Although Luke in Acts 4:5-6 implies that the members of the council include educated scribes, the lack of education he has in mind does not concern the specific kind of scribal learning that members of the Jewish elite received. ${ }^{52}$ If he had wanted to make this point, it would have been sufficient to call Pe-

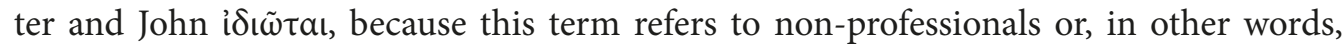
to people who have no special training in a given "art" or "craft" ( $\tau \dot{\varepsilon} \chi \nu \eta) .{ }^{53}$ Rather, Luke intends to picture Peter and John as utterly illiterate laymen who do not possess any professional knowledge neither about the Jewish scriptures nor about any other kind of literature. ${ }^{54}$ This way, he makes it quite plain that they represent a different kind of Christian identity than Apollos or Paul, who both had studied the Scriptures extensively ${ }^{55}$ and who even were partly familiar with Greek philosophy and poetry, as Paul's Areopagus speech shows. ${ }^{56}$ The adjective áypá $\mu \mu \alpha \tau o \varsigma$ in Acts 4:13 is a New Testament hapax legomenon and primarily refers to people who have not attended elementary school and therefore are unable to read or write. As the evidence from contemporaneous Greek writers suggests, ${ }^{57}$ this is the meaning Luke's educated audience was probably most familiar with, although it should be noted that illiteracy per se was not unanimously condemned within the broader context of ancient literature. ${ }^{58}$ Not surprisingly, many commentators advocate a literal reading of Acts 4:13, arguing that Luke makes a statement about the historical reality of the social status and educational background of the earliest adherents of Jesus. ${ }^{59}$ However, Luke's phrasing can also be understood as a literary means to criticize a special kind of

51 Acts 4:1-12.

52 Pace Riesner ${ }^{3} 1988$, 413; Keener 2013, 1154, 1156, and others.

53 See, e. g., Dio Chrys. Orat. 71.5; for further evidence, see Kraus 1999, 436-438.

54 Adams 2015, 132-133; Hilton 2018, 132-133; cf. also the discussion in Keener 2013, 1156-1157. In

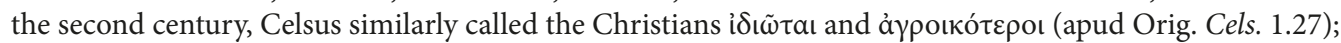
see Hilton 2018, 44-47.

55 Acts $18: 24-25 ; 22: 3$.

56 Cf. Acts 17:22-31, esp. 17:28 (quote of Aratus' Phaenomena); Vollenweider 2012; Jantsch 2017.

57 Dio Chrys. Orat. 13.21; Plut. Pyth. orac. 405c; Epict. Diss. 2.2.22-24; cf. also Xen. Mem. 4.2.20.

58 See Kraus 1999, 438-442, who deals with the documentary papyri in which illiteracy is not disparaged. For a survey of more elitist attitudes to uneducated people in general, see Morgan 1998, 235238, 245-248, 257-259, 268-269. Hilton 2018, 35-57 discusses specifically pagan perceptions and criticism of illiteracy in early Christian groups, focusing mainly on second-century source material.

59 Bovon 1996, 70; Heil 2014, 285. 
education in its relation to the Christian faith. That is where a specific aspect of the contemporaneous reception of Socrates comes into play.

Like Peter and John, the former Athenian stonemason was by no means generally renowned for an elitist type of $\pi \alpha$ ısia among Greek and Roman writers in the early imperial period, ${ }^{60}$ although he was widely recognized as a sage. ${ }^{61}$ According to Seneca, Socrates taught that in order to achieve true happiness and virtus one has to be ready to "appear stupid" (stultum videri) to other people. ${ }^{62}$ To be sure, this does not imply that there is any justified causal relation between the education of philosophers and the (erroneous) judgment that laymen might pass on them. But for present purposes, it is noteworthy to point out that in Seneca's opinion striving to appear erudite is incompatible with the Socratic modus philosophandi. In one of his treatises, Plutarch makes mention of the Hellenistic Peripatetic philosopher Aristoxenus of Tarentum who harshly criticised Socrates for be-

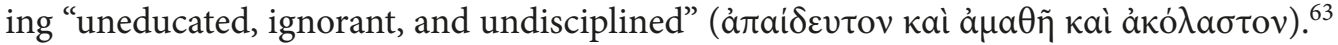
While this negative evaluation is largely motivated by intellectual polemic and definitely not by the Tacitean ideal of sine ira et studio, it nevertheless forms an important part of the nuanced reception of Socrates in the early imperial era. In the writings of Luke's and Plutarch's contemporary Dio Chrysostom, doubtless a member of the educated upper class, we find evidence that Socrates' reputation for being uneducated and uncultured could even be used affirmatively for literary self-fashioning. ${ }^{64}$ In the opening paragraphs of his Olympic Discourse, written c. 97-105 CE, ${ }^{65}$ Dio refers to the exemplum Socratis to dissociate himself from contemporaneous sophists: Employing a thoroughly Platonic template, he envisions them as the enemies of true philosophy ${ }^{66}$ In contrast to the false pretentions of sophists, Dio expressly underscores his ignorance: ${ }^{67} \mathrm{He}$ not only speaks about his "own

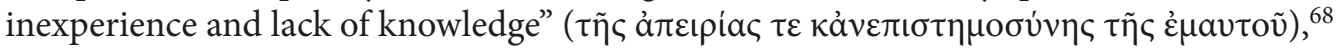

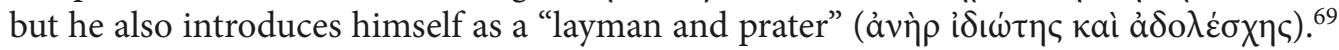
The following lines remarkably exemplify a strategic rhetorical self-abasement of programmatic importance:

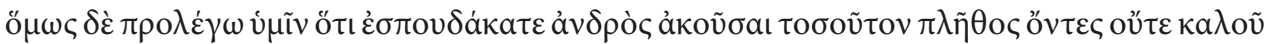

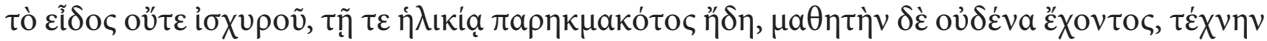

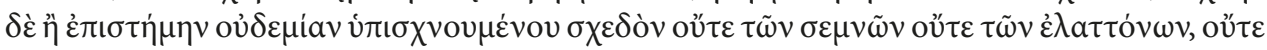

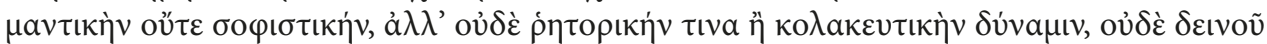

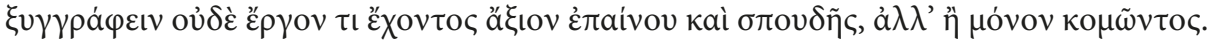

${ }^{60}$ For a positive evaluation of Socrates' education, which is also part of his multi-faceted image in the early imperial period, see, e. g., Valer. Max. Fact. et dict. mem. 6.4 ext. 2 (Socrates autem, Graecae doctrinae clarissimum columen); 8.7 ext. 8 (tantis doctrinae suae divitiis).

${ }^{61}$ Cf., e. g., Valer. Max. Fact. et dict. mem. 3.4 ext. 1 (non solum hominum consensu verum etiam Apollinis oraculo sapientissimus iudicatus); 8.8 ext. 1; Flav. Jos. Contr. Ap. 2.135; Dio Chrys. Orat. 13.30; 72.11; Plut. Arist. 27.3.

${ }^{62}$ Sen. Epist. 71.7: te alicui stultum videri sine.

63 Plut. Herod. malig. $856 \mathrm{c}=$ Aristox. Frg. 55 Wehrli = Frg II. 4.40 Kaiser.

${ }^{64}$ For an analysis of Dio's different methods of self-fashioning, see Krause 2003.

65 Klauck 2000, 25-27.

66 Dio Chrys. Orat. 12.9-15; Döring 1979, 91-94. Dio's texts contain further evidence of a passionate critique of sophists of his day (Wyss 2017, 186-204; Becker 2019a).

67 Dio Chrys. Orat. 12.5; 12.13-14; cf. Plat. Apol. 20c, 23b, and von Arnim 1898, 443-445.

68 Dio Chrys. Orat. 12.14.

${ }^{69}$ Dio Chrys. Orat. 12.16. 
But notwithstanding, I declare to you that, great as is your number, you have been eager to hear a man who is neither handsome in appearance nor strong, and in age is already past his prime, one who has no disciple, who professes, I may almost say, no art or special knowledge either of the nobler or of the meaner sort, no ability either as a prophet or a sophist, nay, not even as an orator or as a flatterer, one who is not even a clever writer, who does not even have a craft deserving of praise or of interest, but who simply — wears his hair long! (Orat. $12.15)^{70}$

Certainly, the statements concerning Dio's education, intelligence, and rhetorical ability can by no means be taken at face value. Rather, they serve two purposes: By fashioning himself as a Socratic philosopher, ${ }^{71}$ Dio, on the one hand, intends to strengthen his authority as a teacher who is about to speak — in the Olympic Discourse (Orat. 12) — about matters of religious art, knowledge of God and philosophical theology in a way that differs from sophistic rhetoric. On the other hand, he presents a critique and revaluation of a certain type of bookish or technical $\pi \alpha$ เ $\delta \varepsilon i a$ characteristic of the sophists. As emphasized in the above-quoted key passage, the distinction between a truly philosophic modus vivendi and the theoretical study of the "arts" ( $\tau \dot{\varepsilon} \chi \nu a \iota)$ and "skills" ( $\dot{\pi} \pi \sigma \tau \tilde{\eta} \mu a \mathrm{l})$ that can be learned in schools and intellectual circles lies at the core of this disdainful reassessment. By taking Socrates as his example, Dio ultimately favours an approach that does not place significance on general studies ( $\dot{\varepsilon} \gamma \kappa u ́ \kappa \lambda \iota \varsigma, \pi \alpha \iota \delta \varepsilon \dot{\alpha} \alpha)$ as a prerequisite for the philosophical life. ${ }^{72}$ In another text devoted to the personal appearance of philosophers (Orat. 72), Dio reiterates his point that true philosophy is not to be confused with any form of schoolish or even higher education by adding to the role model of Socrates that of Diogenes. ${ }^{73}$ Although both philosophers had a reputation for being technically uneducated, Dio says that "though each of us has the garb of Socrates and Diogenes, in intellect we are far from

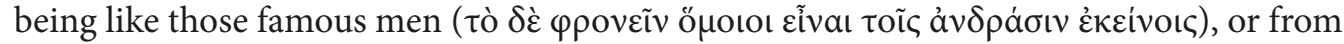

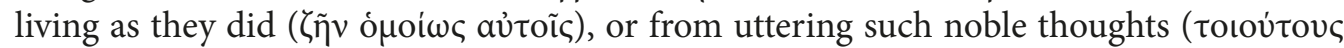
$\lambda$ ójouৎ $\delta \iota \alpha \lambda \dot{\varepsilon} \gamma \varepsilon \sigma \theta a \iota) " .74$ An assessment like that plainly documents that for Dio the educational background, let alone higher education, is of no relevance with regard to philo-

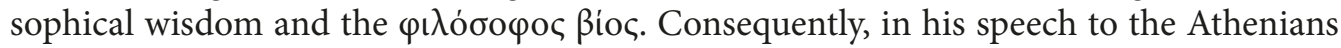
(Orat. 13), he deliberately puts on the mask of Socrates to challenge and to criticize traditional concepts of $\pi \alpha$ เ $\delta \varepsilon i \alpha^{75}$ Against this backdrop, Luke's depiction of Peter's and John's illiteracy appears in a different light.

Dio's use of the example of Socrates (and Diogenes) as an argument in a debate about $\pi \alpha \_\delta$ cia is part of a vibrant Hellenistic and early imperial discourse. Various philosophers from Cynic, Stoic, Cyrenaic, Epicurean, and Sceptic backgrounds are attested to have questioned the relevance of education, or, to put it more precisely, of the

70 Translation by Cohoon 1939, 19.

71 In other texts, Dio also mentions long hair and beard as features of the typical philosopher (Orat. $35.2-3 ; 35.11-12 ; 47.25 ; 72.2$ ). For an annotated (new) edition of some of Dio's texts devoted to the appearance, reputation and character of philosophers, see Nesselrath 2009.

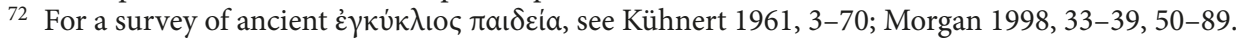

73 Cf. also Dio Chrys. Orat. 4.29-31, where Diogenes voices criticism of traditional $\pi \alpha \_\delta \varepsilon i \alpha$. For the lively reception of Diogenes in philosophical schools and among the pagan educational elite in the early imperial era, see, e. g., Dio's discourses 6, 8, 9, and 10; Epict. Diss. 3.22; Billerbeck 1978, 7-8; Dihle 1989, 91-95. Diog. Laert. Vit. phil. 6.20-81 provides an account of his life that engages with earlier traditions.

74 Dio Chrys. Orat. 72.16; translation by Crosby 1951, 191.

75 Dio Chrys. Orat. 13.14-37. 


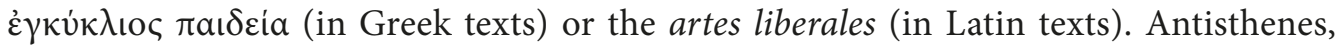
Diogenes, Zeno of Citium, Aristo of Chios, Aristippus, Epicurus, Pyrrho of Elis, Seneca and Epictetus all criticised the $\dot{\varepsilon} \gamma \kappa u ́ \kappa \lambda \iota \varsigma, \pi \alpha \iota \delta \varepsilon$ ia, partly describing it as useless for the philosophical life, partly raising serious doubts about its potential to engender virtue. $^{76}$ Illustrating how education can prevent people from engaging with philosophy, Epictetus describes how certain individuals in his audience reject his teachings be-

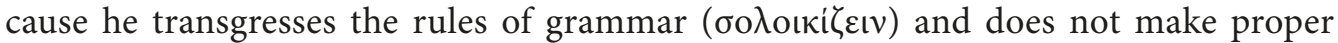
use of Greek in his lectures ( $\beta \alpha \rho \beta \alpha \rho i \zeta \varepsilon ı v) .{ }^{77}$ In one strand of the philosophical critique of education, the question was discussed whether $\gamma \rho \dot{\alpha} \mu \mu \alpha \tau \alpha$ and litterae are needed at all to gain wisdom; this helps to shed new light on the connotation of à $\gamma \rho \alpha \operatorname{\mu } \mu \mu \alpha \tau o \varsigma$ in Acts $4: 13$. Antisthenes is known to have taught "that those who have acquired a sound

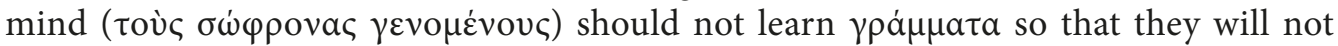

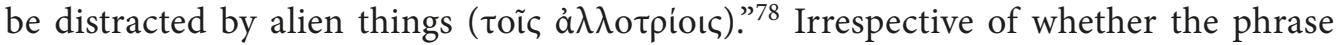
$\gamma \rho \dot{\alpha} \mu \mu \alpha \tau \alpha \mu \alpha v \theta \dot{\alpha} v \varepsilon \varepsilon^{\prime}$ here refers to elementary education in reading and writing or to the more advanced study of grammar and literature at school, Antisthenes' critique is severe and fundamental, presenting the $\gamma \rho \alpha \dot{\alpha} \mu \mu \alpha \tau \alpha$ as obstacles that prevent students from practicing philosophy as they should. ${ }^{79}$ In similar fashion, in his $88^{\text {th }}$ epistle to Lucilius, Seneca denies that the liberalia studia are necessary to attain virtue and wisdom, ${ }^{80}$ raising the provocative question: "Why should I think that the one who does not know letters will not be a sage, when wisdom is not in letters?" (Quid est autem quare existimem non futurum sapientem eum qui litteras nescit, cum sapientia non sit in litteris?). ${ }^{81}$ In another epistle, Seneca juxtaposes contemporaneous philosophical teaching and the Socratic approach: Rather than paying attention to teachers who reduce philosophy to mere "word-play" (ludus litterarius) and "syllables" (syllabae), trying to make it "difficult" (difficilis), Lucilius is supposed to follow those who invented true philosophy, such as Socrates, "who summoned the whole of philosophy back to matters of conduct" (qui totam philosophiam revocavit ad mores). ${ }^{82}$

Given that Luke and his educated audience were familiar with this Socratic element of contemporaneous first century discourse on the disadvantages of education, the picture of Peter (and John) in Acts 4:13 gains an important nuance. The recipients of the auctor ad Theophilum can see, as it were, a philosophical Peter (and John), irrespective of the fact that the apostles do not teach philosophical wisdom, but bring the

76 Kühnert 1961, 99-111; Stückelberger 1965, 31-39; Becker 2019c, 205-206; see, e. g., Epic. Frg. 227 Usener; Cic. De fin. 1.71-72; Sen. Epist. 88; Epict. Diss. 1.4.5-12; Diog. Laert. Vit. phil. 2.71; 2.79; 6.27$28 ; 6.73 ; 6.103-104 ; 7.32$.

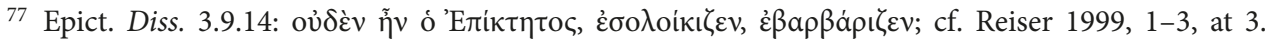
Avoiding barbarismi ac soloecismi was an important part of formal rhetorical training (Quint. Inst. 1.5.5-54; Siebenborn 1976, 43-52).

78 Diog. Laert. Vit. phil. 6.103.

79 Kühnert 1961, 101 n. 1. Kühnert also points out that the Cynics were more hostile to education in theory than in practice.

80 Sen. Epist. 88.32: Potest quidem etiam illud dici, sine liberalibus studiis veniri ad sapientiam posse; quamvis enim virtus discenda sit, tamen non per haec discitur; for a similar argument, see Dio Chrys. Orat. 4.29-31.

${ }^{81}$ Sen. Epist. 88.32. In like manner, the Epicureans are said to have encouraged prospective students to avoid the $\mu a \theta \eta \dot{\mu} \mu \alpha \alpha$ (Plut. Contr. Epic. beat. 1094d-e).

82 Sen. Epist. 71.6-7. For a similar argument, see Epict. Diss. 2.16.32-36, where Epictetus puts the study of "introductions" ( $\varepsilon i \sigma \alpha \gamma \omega \gamma \alpha i)$ and the reading of Chrysippean treatises into contrast with the modus vivendi (and moriendi) of Socrates and Diogenes. 
tidings of salvation in Jesus' name ${ }^{83}$ Read in this light, the message of the text is not so much concerned with historical information about the actual lack of education of early Christian teaching figures like Peter, and even less with the depiction of Christianity as a religion of the uneducated. Rather, as $\gamma \rho \alpha \dot{\mu} \mu \alpha \tau \alpha$ and $\pi \alpha$ เ $\delta \varepsilon i \alpha$ are equally irrelevant for true philosophy, so faith in the saving and healing power of Jesus' name does not require any educational prerequisites. ${ }^{84}$ Moreover, Luke's reference to the "boldness" ( $\pi \alpha \rho \rho \eta \sigma i a)$ of the apostles clearly expresses the opinion that there is no need for uneducated people to feel ashamed of speaking about their religion. ${ }^{85}$ Hence, this Socratic reminiscence marks common ground between Christianity and Greco-Roman philosophy, and it helps to see beyond a portrayal of the apostles which supposedly conveys the notion that they are simpletons. If an erudite orator like Dio can refer to the exemplum

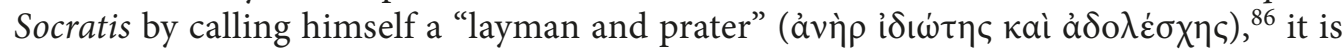
not unreasonable to think that one of the most educated authors of the New Testament could have had more in mind when he penned down the words ä $v \theta \rho \omega \pi$ o à $\gamma \rho \alpha$ á $\mu \mu \alpha \tau o$ í

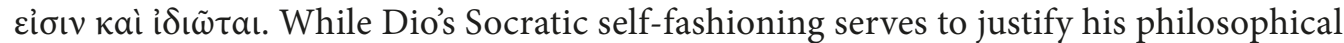
authority, Luke is more concerned with Peter's divine authority: Not only is he introduced as speaking with the help of the holy Spirit, ${ }^{87}$ his lack of education also is supposed to show that what he proclaims about Jesus is not the product of human invention or sophistication. ${ }^{88}$ The support of the divine $\pi v \varepsilon \tilde{v} \mu \alpha$ is a major difference vis-à-vis the pursuit of wisdom among contemporaneous philosophers.

\section{Obeying God}

Ever since Plato's depiction in the Apology, Socrates represents a type of philosopher who perceives himself as being divinely sent to people in order to teach them true philosophical virtue. ${ }^{89}$ As shall be seen, this aspect of the reception of Socrates is of special significance for Epictetus, who on his part developed the concept of the ideal Cynic as being a messenger sent by Zeus. ${ }^{90}$ In similar fashion, Luke presents the apostles as being sent by the risen Jesus, who tells them that they will receive the empowerment of the holy Spirit in order to be his witnesses "to the end of the earth" ${ }^{91}$ Yet, having a message to spread is not the only thing which Socrates and the apostles have in common; it is also interesting to note that both in Luke and in Epictetus their obedience to God is challenged in a very spe-

83 Acts 4:12.

84 Cf. von Campenhausen 1960, 30. As Erlemann 2000, 89-90 puts it: “Die Wahrheit der neuen Lehre ist vom Bildungsniveau ihrer Träger und von der (defizitären) sprachlichen Form unabhängig."

85 The same point is conveyed through the portrayal of the simple tentmakers Aquila and Priscilla (Acts 18:2-3), who do not shy away from teaching the erudite Alexandrian scholar and missionary Apollos about certain details of the Christian faith (Acts 18:24-26); cf. Lentz 1993, 17.

86 Dio Chrys. Orat. 12.16.

87 Acts 4:8; Hilton 2018, 155-161.

88 Lentz 1993, 21; Erlemann 2000, 87-90; cf. Orig. Cels. 1.62; Adams 2015, 134.

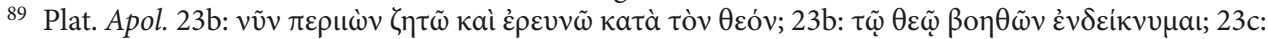

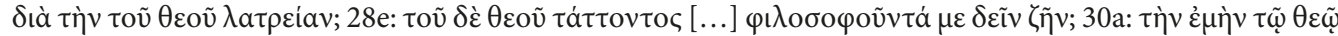

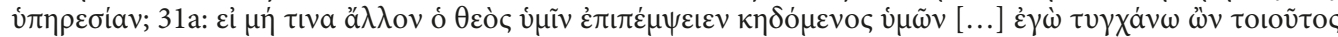

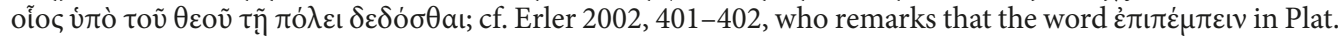
Apol. 31a has a religious ring to it, indicating a divine sending.

90 Epict. Diss. 3.22.23; 3.22.45-46; Billerbeck 1978, 78-79, 106-107.

91 Acts 1:8. 
cific judicial context. ${ }^{92}$ Luke's narratives in Acts 4:2-22 and 5:17-42 are especially relevant in this regard, because they both lead up to a climax showing and underscoring that Jesus' witnesses remain faithful. Although John is named repeatedly in those chapters, ${ }^{93}$ the spotlight clearly is on Peter. ${ }^{94}$ As representatives of the apostles in a pars pro toto sense, ${ }^{95}$ they teach about Jesus and perform miracles ${ }^{96}$ until they are twice arrested, incarcerated and interrogated by Jewish authorities. In both hearings, Peter, John and the other apostles are told by the Sanhedrin "not at all to utter a sound or to teach in the name of Jesus" (Acts

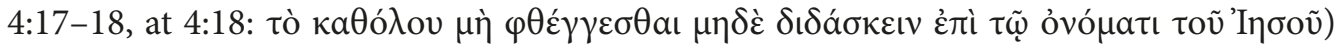

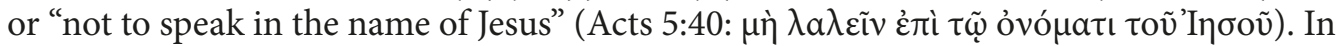
both cases Peter and John do not obey the orders of the court, indicating twice the reasons for their action. The first passage reads:

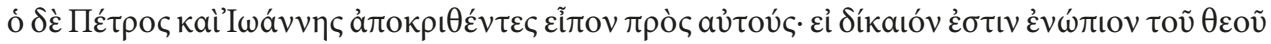

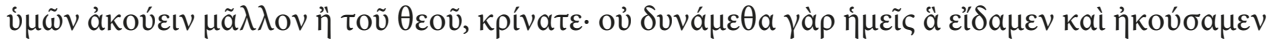

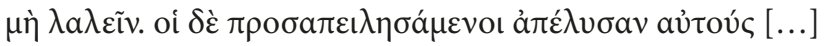

But Peter and John said, answering them: "Whether it is right in the sight of God to listen to you rather than to God, you (must) judge. For we cannot but speak of what we have seen and heard." But they, issuing threats, let them go [...]. (Acts: 4:19-21a)

The second passage reads:

'А

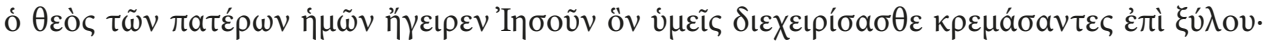

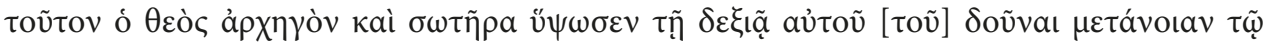

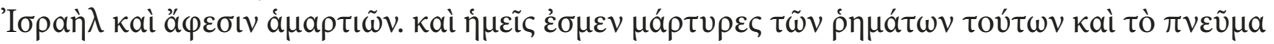

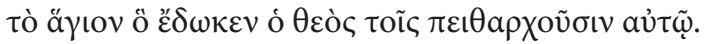

But Peter and the apostle's, answering, said: “One has to obey God rather than men. The God of our fathers has raised Jesus, whom you killed by hanging him on a piece of wood [sc. cross]. This one God has exalted by his right hand as leader and saviour, to give repentance to Israel and forgiveness of sins. And we are witnesses to these events, and so is the holy Spirit whom God has given to those who obey him." (Acts 5:29-32)

Both passages revolve thematically around obedience to God, ${ }^{97}$ erasing almost all memory of Peter's threefold denial of Jesus. ${ }^{98}$ The witness terminology in Acts 5:32 clearly re-

92 Socrates' imprisonment as well as his trial were well-known among the educated first century elite, see, e. g., Sen. Epist. 24.4; 28.8; 67.7; 70.9; 71.17; Epict. Diss. 1.12.23; 2.2.15; 2.5.18-19; 4.4.22; Dio Chrys. Orat. 43.8-12; Plut. De tranquil. anim. 466e.

93 Acts $4: 6 ; 4: 13 ; 4: 19$.

94 Acts $4: 8 ; 4: 13 ; 4: 19 ; 5: 3 ; 5: 8-9 ; 5: 15 ; 5: 29$.

95 Acts $4: 33 ; 4: 35-37 ; 5: 2 ; 5: 12 ; 5: 18 ; 5: 29 ; 5: 40$.

96 Acts 3:11-26; 5:12-16.

97 The Gethsemane episode provides further evidence of the importance of this theological theme in

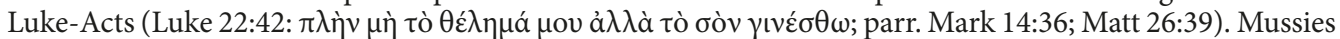
1972, 105 quotes Dio Chrys. Orat 30.8 as a parallel to the Lukan verse illustrating the confidence of dying philosophers (such as Charidemus) in God's good will. Of course, one might also think of Socrates' response

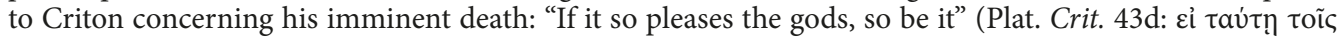

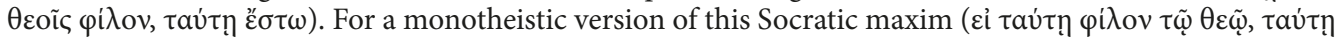

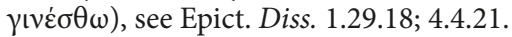

${ }^{98}$ Cf. Luke 22:54-62; Mark 14:53-54.66-72; Matt 26:57-58.69-75. Peter's change of behaviour can best be explained by the fact that in Acts Luke is eager to portray the apostles as being divinely sent as 
fers back to Peter's sermons in Acts 3:15, 2:32, and to the words of the risen Lord in Acts

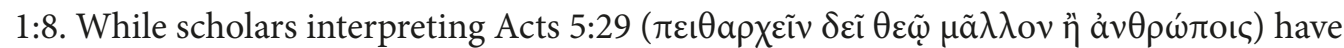
drawn attention to Plato's depiction of Socrates' trial and his decision to obey God rather than the judges, ${ }^{99}$ it has largely been neglected that for Luke's contemporary Epictetus Plato's Apology also serves to illustrate the importance of obeying God. Epictetus' main point in quoting passages from the Apology which deal with the trial of Socrates is to show how a man acts who fully realizes that he is akin to God. Paraphrasing Plato's words, the Roman Stoic depicts Socrates saying the following:

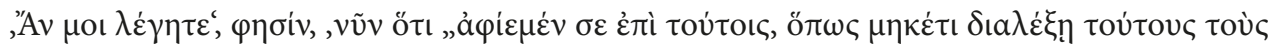

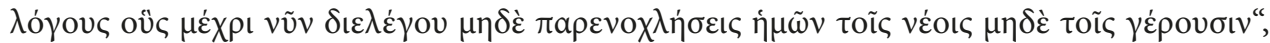

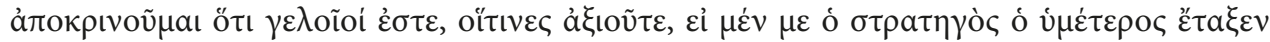

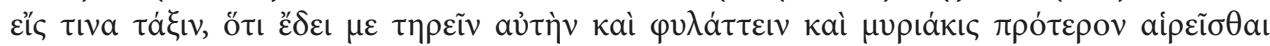

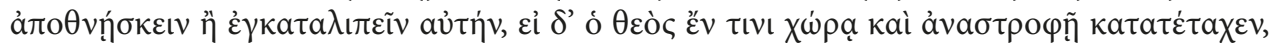

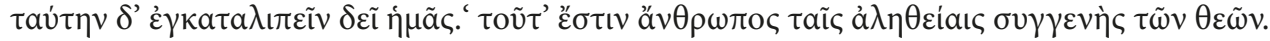

"If you tell me now," says he [sc. Socrates], "We will acquit you on these conditions, namely, that you will no longer engage in these discussions which you have conducted hitherto, nor trouble either the young or the old among us', I will answer, 'You make yourselves ridiculous by thinking that, if your general had stationed me at any post, I ought to hold and maintain it and choose rather to die ten thousand times than to desert it, but if God has stationed us in some place and in some manner of life we ought to desert that." This is what it means for a man to be in very truth a kinsman of the gods. ${ }^{100}$ (Epict. Diss. 1.9.23-25)

Although Luke in Acts 4-5 neither employs the figurative language of holding a position in the military sense to describe the apostles' faithfulness in spreading the message of Jesus, nor devotes attention to the philosophical theme of kinship with God, ${ }^{101}$ there is an interesting analogy of threat and theological justification: While Peter and the apostles are forbidden by the Sanhedrin to speak in the name of Jesus, Socrates' judges want to force him to stop teaching philosophy. ${ }^{102}$ Unimpressed by the threats, both the Lukan Peter and the Epictetean Socrates are determined to continue to do what they do, ${ }^{103}$ providing each the same genuinely theological reason: Peter refers to obedience to God in a general sense, and Socrates pictures himself more specifically as a soldier who has to obey orders without deserting or defecting, alluding to the divine command that he should live the philosophical life and teach the Athenians virtue. ${ }^{104}$ Epictetus only implies that obeying the judges

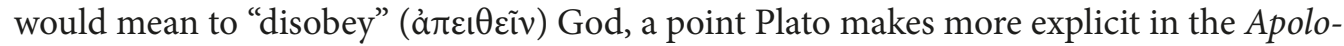
$g y .{ }^{105}$ However, in another of his dissertations the Roman Stoic expressis verbis combines the image of a soldier holding his position with a Socratic theology of obedience:

witnesses of the risen Lord (Acts 1:8). As such, they are inspired and strengthened by the holy Spirit (Acts $1: 8 ; 2: 1-4 ; 4: 8 ; 4: 31 ; 5: 32)$, who does not play any role in the episode of Peter's denial of Jesus.

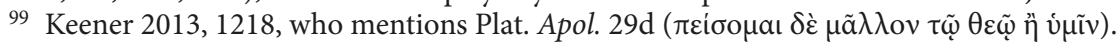

100 Translation by Oldfather 1961, 71 .

101 This he clearly does later in Acts 17:28, where the Lukan Paul quotes from the proem of Aratus' Phaenomena.

102 Acts 4:17-18; 5:40; Epict. Diss. 1.9.23; cf. Plat. Apol. 29c.

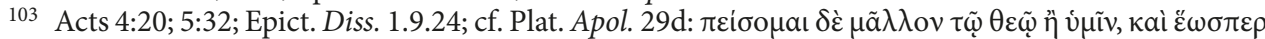

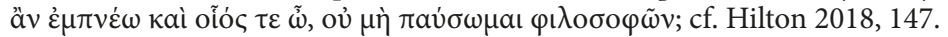

104 Acts 4:19; 5:29; Epict. Diss. 1.9.24; cf. Plat. Apol. 28d-e, 29d. On Socrates' military service, see Plat.

Lach. 181b; Plat. Symp. 220c-221c; Sen. Epist. 104.27 (labores militares); Epict. Diss. 4.1.160.

105 Plat. Apol. 37e-38a. 


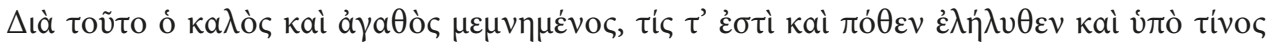

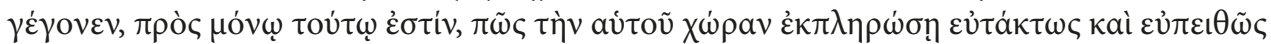
$\tau \tilde{\omega} \theta \varepsilon \tilde{\omega}$.

For this reason the good and excellent man, bearing in mind who he is, and whence he has come, and by whom he was created, centres his attention on this and this only, how he may fill his place in an orderly fashion, and with due obedience to God. ${ }^{106}$ (Epict. Diss. 3.24.95)

In the context of this passage, Socrates is explicitly mentioned as an example of the "good

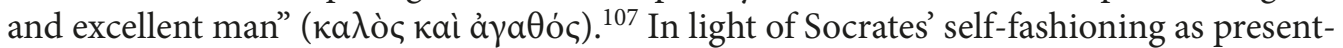
ed by Epictetus, Luke's Peter embodies a Socratic virtue. ${ }^{108}$

\section{Conclusion}

In a very general sense, the findings of the present study confirm that the work of learned first-century Christian writers like Luke, whose style and thought is otherwise deeply influenced by the Greek Old Testament (Septuagint), fits well within the context of contemporaneous Greco-Roman intellectual discourses. ${ }^{109}$ Against the backdrop of first and early second-century receptions of the exemplum Socratis the great Athenian philosopher and the apostle Peter share important discursive similarities. Of course, in almost all passages dealt with here Peter is not the only character to be associated with Socratic traits. Nevertheless, it goes without saying that the disciple-turned-fisherman from Galilee joins Jesus and Paul in being one of Luke's major protagonists, and he undoubtedly has a special status among the Twelve: In many instances, he acts as the spokesperson for the group, ${ }^{110}$ and when several disciples are named in a list, Peter ranks first. ${ }^{111}$ For this reason, he is the main object of socratization as far as the inner circle of Jesus is concerned. In particular, two aspects contribute to the Socratic colouring of the image of Peter in LukeActs, namely Socrates' lack of formal education and his obedience to God. It is important to underscore that these aspects are peculiar to Luke, not being attested explicitly elsewhere, neither in the Synoptic Gospels nor in the Gospel of John. ${ }^{112}$ Hence, in addition to

106 Translation by Oldfather 1959, 215.

107 Epict. Diss. 3.24.99; cf. Döring 1979, 52-55. Generally, Epictetus places great emphasis on the gods'

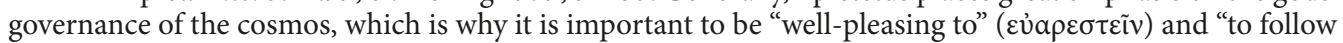

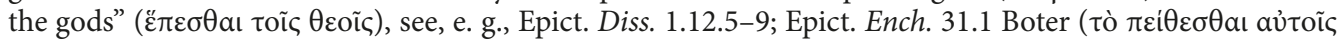

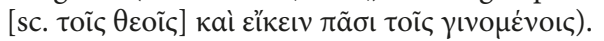

108 Of course, it should be kept in mind that obeying God was a general concern to various philosophers in the early imperial period, with Socrates being one, albeit very significant, example; cf. Dio Chrys. Orat.

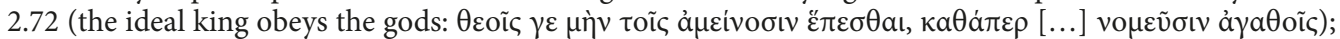
Orat. 13.10 ( $\pi \varepsilon \dot{\varepsilon} \theta \varepsilon \sigma \theta$ a $\tau \tilde{\omega} \tilde{e} \theta \varepsilon \tilde{\omega}$ in the context of oracular utterances); Muson. Diatr. 16, p. 87.9-10 Hense:

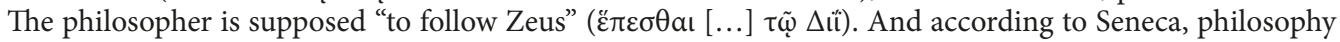
"will admonish us that we obey God with pleasure" (Sen. Epist. 16.5: adhortabitur ut deo libenter pareamus).

109 Feldmeier 2012; Becker 2016b; Becker 2020. Niehoff 2018 makes a similar point in regard to the works of Philo, demonstrating that his intellectual development was heavily affected by both Greek philosophy and his contacts with the intellectual community in Rome.

110 This can clearly be seen, e. g., in Luke 8:45; 9:33; 12:41; 18:28; Acts $1: 15 ; 2: 14 ; 4: 8 ; 5: 3$.

111 Luke $6: 14 ; 8: 51 ; 9: 28 ; 9: 32 ; 22: 8$; Acts $1: 13 ; 1: 15 ; 2: 14 ; 2: 37 ; 3: 1 ; 3: 3 ; 4: 13 ; 4: 19 ; 8: 14$.

112 The image of an illiterate and largely uneducated Peter is, by the way, not the only image of the apostle to be found in the New Testament (cf. Becker 2019b, 172 n. 58). On the contrary, First and especially Second Peter, despite their pseudonymity, promote the image of Peter as a quite educated apostle who writes a fairly polished Greek, who shows acquaintance with philosophical terminology and doctrines (cf. 2 Peter

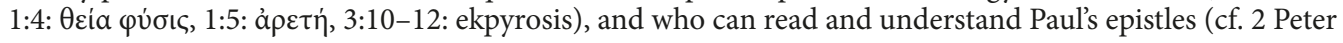


the episodic portrayals of Jesus through the blurry lens of the Socrates moriens and of Paul through the sharper lens of the Socrates philosophans, Peter serves as yet another literary projection screen used to display - at certain points in the narrative - important nuances of the multi-faceted picture of Socrates. While Christian theologians, from the second century onwards, explicitly labelled the Christian religion as the true philosophy, ${ }^{113}$ Luke is among those New Testament authors who ultimately paved the way that was to lead in this direction. ${ }^{114}$ The reception of Socrates, reflected in the characterization of three of his main protagonists with varying degrees of lucidity, is, as it were, one of the many intellectual cobblestones he used to build that road. ${ }^{115}$

\section{References}

Adams S. Luke-Acts II: New Testament. Encyclopedia of the Bible and its Reception 2019, 17, $143-150$.

Adams S. A. The Tradition of Peter's Literacy: Acts, 1 Peter, and Petrine Literature, in: H. K. Bond; L. W. Hurtado (eds). Peter in Early Christianity. Grand Rapids, MI, Eerdmans, 2015, 130-145.

Andresen C. Logos und Nomos. Die Polemik des Kelsos wider das Christentum. AZK 30; Berlin, De Gruyter, 1955.

Armitage D. J. Theories of Poverty in the World of the New Testament. WUNT II 423; Tübingen, Mohr Siebeck, 2016.

Becker M. Lukas und Dion von Prusa. Das lukanische Doppelwerk im Kontext paganer Bildungsdiskurse. Studies in Cultural Contexts of the Bible 3; Paderborn, Brill - Ferdinand Schöningh, 2020 (in press).

Becker M. A Template for Picturing Rivals? Paul's Depictions of Opponents and the Elements of AntiSophistic Polemic. Biblische Notizen 2019, 180, 105-129. (= Becker 2019a)

Becker M. Origen the Sophist: Anti-Sophistic Polemic in Porphyry's Contra Christianos. Vigiliae Christianae 2019, 73, 159-173. (= Becker 2019b)

Becker M. Zwischen Gelehrsamkeit und Angleichung an Gott. Bildung in der spätantiken Philosophie, in: P. Gemeinhardt (ed.), Was ist Bildung in der Vormoderne? SERAPHIM 4; Tübingen, Mohr Siebeck, 2019, 205-228. (=Becker 2019c)

Becker M. Ergriffen von Liebe zum Götterbild. Statuen- und Bildhauermetaphorik in der Palinodie des Phaidros Platons, in: D. Koch; I. Männlein-Robert; N. Weidtmann (eds.), Platon und die Bilder. AntikeStudien 3; Tübingen, Attempto, 2016, 8-27. (= Becker 2016a)

Becker M. Der Vergleich des Lebens mit einem Gastmahl als Verhaltensanweisung. Lk 14,7-11 und 22,2627 im Lichte von Texten Epiktets und Dions von Prusa. Zeitschrift für die neutestamentliche Wissenschaft 2016, 107, 206-231. (= Becker 2016b)

Billerbeck M. Epiktet: Vom Kynismus. Hrsg. und übersetzt mit einem Kommentar. PhilAnt 34; Leiden, Brill, 1978.

Bostick W. F. Jesus and Socrates. The Biblical World 1916, 47, 248-252.

Bovon F. Das Evangelium nach Lukas. 2. Teilband (Lk 9,51-14,35). EKK III/2; Zürich — Neukirchen-Vluyn, Benziger - Neukirchener Verlag, 1996.

Burchard C. Der dreizehnte Zeuge. Traditions- und kompositionsgeschichtliche Untersuchungen zu Lukas' Darstellung der Frühzeit des Paulus. FRLANT 103; Göttingen, Vandenhoeck \& Ruprecht, 1970.

Cadbury H. J. The Making of Luke-Acts. London, S. P. C. K, ${ }^{2} 1958$.

Cohoon J. W. (ed.) Dio Chrysostom: Discourses 12-30. With an English Translation by J. W. Cohoon. LCL 339; Cambridge, $\mathrm{Ma}$ - London, Harvard University Press, 1939.

Cowan J. A. Paul and Socrates in Dialogue: Points of Contact between the Areopagus Speech and the Apology. New Testament Studies, forthcoming.

3:15-16); for more details on the educational background of the authors of First and Second Peter, see Grünstäudl 2013, 12-14; Adams 2015, 134-137; Kraus 2017, 234-246.

113 Löhr 2010.

114 Cf. Feldmeier 2012, 92-93.

115 For other intellectual 'cobblestones' Luke used, see Becker 2020. 
Crosby H.L. (ed.) Dio Chrysostom: Discourses 61-80, Fragments, Letters. With an English Translation by H. L. Crosby. LCL 385; Cambridge, Ma - London, Harvard University Press, 1951.

Danzig G. Apologizing for Socrates. How Plato and Xenophon Created Our Socrates. Lanham, Lexington Books, 2010.

Dihle A. Die griechische und lateinische Literatur der Kaiserzeit. Von Augustus bis Justinian. Munich, C. H. Beck, 1989.

Döring K. Exemplum Socratis. Studien zur Sokratesnachwirkung in der kynisch-stoischen Popularphilosophie der frühen Kaiserzeit und im frühen Christentum. Hermes EZ 42; Wiesbaden, Steiner, 1979.

Erlemann K. Lizenz zum Reden. Die lk. Apostel zwischen Geist und Rhetorik, in: A. von Dobbeler; K. Erlemann; R. Heiligenthal (eds.), Religionsgeschichte des Neuen Testaments. FS K. Berger. Tübingen - Basel, Francke, 2000, 79-91.

Erler M. Hilfe der Götter und Erkenntnis des Selbst. Sokrates als Göttergeschenk bei Platon und den Platonikern, in: T. Kobusch; M.Erler (eds.), Metaphysik und Religion. Zur Signatur des spätantiken Denkens. BzA 160; Munich - Leipzig, K. G. Saur, 2002, 387-413.

Feldmeier R. Before the Teachers of Israel and the Sages of Greece: Luke-Acts as a Precursor of the Conjunction of Biblical Faith and Hellenistic Education, in: I. Tanaseanu-Döbler; M. Döbler (eds.), Religious Education in Pre-Modern Europe. NBS 140; Leiden - Boston, Brill, 2012, 77-95.

Gooch P.W. Reflections on Jesus and Socrates. Word and Silence. New Haven - London, Yale University Press, 1996.

Grünstäudl W. Petrus Alexandrinus. Studien zum historischen und theologischen Ort des zweiten Petrusbriefes. WUNT II 353; Tübingen, Mohr Siebeck, 2013.

Hanges J.C. Socrates and Jesus: Comparing Founder-Figures in the Classroom, in: T. A.Idinopulos; B. C. Wilson; J. C. Hanges (eds.), Comparing Religions. Possibilities and Perils? NBS-SHR 113; Leiden Boston, Brill, 2006, 143-173.

Heil C. Analphabet oder Rabbi? Zum Bildungsniveau Jesu, in: C. Heil (ed.), Das Spruchevangelium Q und der historische Jesus. SBAB 58; Stuttgart, Katholisches Bibelwerk, 2014, 265-291.

Heininger B. Das Paulusbild der Apostelgeschichte und die antike Biographie, in: M.Erler; S. Schorn (eds.), Die griechische Biographie in hellenistischer Zeit. BzA 245; Berlin - New York, De Gruyter, 2007, 407429.

Heininger B. Einmal Tarsus und zurück (Apg 9,30; 11,25-26). Paulus als Lehrer nach der Apostelgeschichte. Münchener Theologische Zeitschrift 1998, 49, 125-143.

Hays C. M. Luke's Wealth Ethics. A Study in Their Coherence and Character. WUNT II 275; Tübingen, Mohr Siebeck, 2010.

Hilton A. R. Illiterate Apostles. Uneducated Early Christians and the Literates Who Loved Them. LNTS 541; London - New York, Bloomsbury, T\&T Clark, 2018.

Horn F. W. Glaube und Handeln in der Theologie des Lukas. GTA 26; Göttingen, Vandenhoeck \& Ruprecht, ${ }^{2} 1986$.

Jantsch T. „Sokratische“ Themen in der Areopagrede. Apg 17,22-31 im Kontext der antiken Philosophiegeschichte. Early Christianity 2017, 8, 481-503.

Keener C. S. Acts. An Exegetical Commentary. Vol. 3 (15:1-23:35). Grand Rapids, MI, Baker Academic, 2014.

Keener C. S. Acts. An Exegetical Commentary. Vol. 2 (3:1-14:28). Grand Rapids, MI, Baker Academic, 2013.

Keener C. Acts. An Exegetical Commentary. Vol. 1 (Introduction and 1:1-2:47). Grand Rapids, MI, Baker Academic, 2012.

Klauck H.-J. Dion von Prusa: Olympische Rede oder Über die erste Erkenntnis Gottes. Eingeleitet, übersetzt und interpretiert von H.-J. Klauck. Mit einem archäologischen Beitrag von B. Bäbler. SAPERE 2; Darmstadt, Wissenschaftliche Buchgesellschaft, 2000.

Kramer H. Lukas als Ordner des frühchristlichen Diskurses um „Armut und Reichtum“ und den „Umgang mit materiellen Gütern". Eine überlieferungsgeschichtliche und diskurskritische Untersuchung zur Besitzethik des Lukasevangeliums unter besonderer Berücksichtigung des lukanischen Sonderguts. NET 21; Tübingen, Francke, 2015.

Kraus T. J. “Anders und doch Teil des Ganzen!?” oder Über Asianismus, das "Verwunderliche” an 2 Petr und "Verwunderliches" über ihn, in: W. Grünstäudl; U. Poplutz; T. Nicklas (eds.), Der zweite Petrusbrief und das Neue Testament. WUNT 397; Tübingen, Mohr Siebeck, 2017, 231-253.

Kraus T. J. 'Uneducated, 'Ignorant', or Even 'Illiterate'? Aspects and Background for an Understanding of АГРАMMATOI (and I $\triangle \mathrm{I} \Omega \mathrm{TAI}$ ) in Acts 4.13. New Testament Studies 1999, 45, 434-449. 
Krause C. Strategie der Selbstinszenierung. Das rhetorische Ich in den Reden Dions von Prusa. SG 16; Wiesbaden, Reichert, 2003.

Kühnert F. Allgemeinbildung und Fachbildung in der Antike. Berlin, Akademie-Verlag, 1961.

Lentz J. C. Luke's Portrait of Paul. SNTS. MS 77; Cambridge, CUP, 1993.

Löhr W. Christianity as Philosophy. Problems and Perspectives of an Ancient Intellectual Project. Vigiliae Christianae 2010, 64, 160-188.

Moore C. (ed.) Brill's Companion to the Reception of Socrates. BCCR 18; Leiden - Boston, Brill, 2019.

Morgan T. Literate Education in the Hellenistic and Roman Worlds. Cambridge, CUP, 1998.

Mussies G. Dio Chrysostom and the New Testament. SCHNT 2; Leiden, Brill, 1972.

Nesselrath, H.-G. (ed.) Dion von Prusa: Der Philosoph und sein Bild. Eingeleitet, ediert, übersetzt und mit interpretierenden Essays versehen von E.Amato, S. Fornaro, B.E.Borg, R.Burri, J.Hahn, I.Ramelli, J. Schamp. SAPERE 13; Tübingen, Mohr Siebeck, 2009.

Niehoff M. R. Philo of Alexandria: An Intellectual Biography. New Haven - London, Yale University Press, 2018.

Niehoff M. R. Jewish Exegesis and Homeric Scholarship in Alexandria. Cambridge, CUP, 2011.

Oldfather W. A. (ed.) Epictetus. With an English Translation by W. A. Oldfather. Vol. I: Discourses, Books I and II. Reprint. LCL; Cambridge, Ma - London, Harvard University Press - William Heinemann, 1961.

Oldfather W. A. (ed.) Epictetus. With an English Translation by W. A. Oldfather. Vol. II: Discourses, Books III and IV, the Manual, and Fragments. Reprint. LCL; Cambridge, Ma - London, Harvard University Press - William Heinemann, 1959.

Piccione R.M. De Vita Mosis I 60-62. Philon und die griechische $\pi a$ scia, in: R. Deines; K.-W.Niebuhr (eds.), Philo und das Neue Testament. Wechselseitige Wahrnehmungen. WUNT 172; Tübingen, Mohr Siebeck, 2004, 345-357.

Plümacher E. Lukas als hellenistischer Schriftsteller. Studien zur Apostelgeschichte; StUNT 9; Göttingen, Vandenhoeck \& Ruprecht, 1972.

Priestly J. Socrates and Jesus Compared. Philadelphia, P. Byrne, 1803.

Prostmeier F. R. „Was will wohl dieser Schwätzer sagen?“ Bildung und religiöses Wissen im 2. Jahrhundert n. Chr., in: P. Gemeinhardt; S. Günther (eds.), Von Rom nach Bagdad. Bildung und Religion von der römischen Kaiserzeit bis zum klassischen Islam, Tübingen, Mohr Siebeck, 2013, 127-162.

Reiser M. Die Stellung der Evangelien in der antiken Literaturgeschichte. Zeitschrift für die neutestamentliche Wissenschaft 1999, 90, 1-27.

Riesner R. Jesus als Lehrer. Eine Untersuchung zum Ursprung der Evangelien-Überlieferung. WUNT II 7; Tübingen, Mohr Siebeck, ${ }^{3} 1988$.

Rowe C. K. The Grammar of Life: The Areopagus Speech and Pagan Tradition. New Testament Studies 2011, $57,31-50$.

Schnelle U. Die ersten 100 Jahre des Christentums 30-130 n. Chr. Die Entstehungsgeschichte einer Weltreligion. UTB 4411; Göttingen, Vandenhoeck \& Ruprecht, ${ }^{2} 2016$.

Schnelle U. Das frühe Christentum und die Bildung. New Testament Studies 2015, 61, 113-143.

Siebenborn E. Die Lehre von der Sprachrichtigkeit und ihren Kriterien. Studien zur antiken normativen Grammatik. StAPh 5; Amsterdam, Grüner, 1976.

Sterling G. Mors philosophi: The Death of Jesus in Luke. Harvard Theological Review 2001, 94, 383-402.

Stückelberger A. Senecas 88. Brief. Über Wert und Unwert der Freien Künste. Text - Übersetzung - Kommentar. BKA 7; Heidelberg, Winter, 1965.

van Kooten G. The Last Days of Socrates and Christ: Euthyphro, Apology, Crito, and Phaedo Read in Counterpoint with John's Gospel, in: A. Klostergaard Petersen; G.van Kooten (eds). Religio-Philosophical Discourses in the Mediterranean World. From Plato, through Jesus, to Late Antiquity. APhR 1; Leiden Boston, Brill, 2017, 219-243.

Vegge T. Paulus und das antike Schulwesen. Schule und Bildung des Paulus. BZNW 134; Berlin - New York, De Gruyter, 2006.

Vollenweider S. „Mitten auf dem Areopag“. Überlegungen zu den Schnittstellen zwischen antiker Philosophie und Neuem Testament. Early Christianity 2012, 3, 296-320.

von Arnim H. Leben und Werke des Dio von Prusa. Mit einer Einleitung: Sophistik, Rhetorik, Philosophie in ihrem Kampf um die Jugendbildung. Berlin, Weidmann, 1898.

von Campenhausen H. Fr. Glaube und Bildung im Neuen Testament, in: H. Fr. von Campenhausen, Tradition und Leben. Kräfte der Kirchengeschichte. Aufsätze und Vorträge. Tübingen, Mohr Siebeck, 1960, $17-47$. 
Wehnert J. Apollos, in: T. Georges; F. Albrecht; R. Feldmeier (eds.), Alexandria. COMES 1; Tübingen, Mohr Siebeck, 2013, 403-412.

Wenley R. M. Socrates and Christ. A Study in the Philosophy of Religion. Edinburgh - London, William Blackwood, 1889.

Wolter M. Das Lukasevangelium. HNT 5; Tübingen, Mohr Siebeck, 2008.

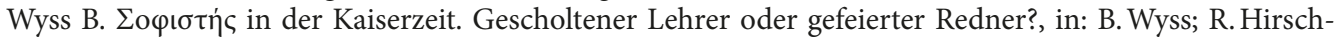
Luipold; S.-J. Hirschi (eds.) Sophisten in Hellenismus und Kaiserzeit. Orte, Methoden und Personen der Bildungsvermittlung. STAC 101; Tübingen, Mohr Siebeck, 2017, 177-212.

Received: September 23, 2019 Accepted: March 03, 2020 